by Jesús Martínez-Frías ${ }^{1,3}$, José Luis González ${ }^{2}$ and Fernando Rull Pérez ${ }^{1,3}$

\title{
Geoethics and Deontology: From fundamentals to applications in Planetary Protection
}

\author{
1 Centro de Astrobiologia CSIC-INTA, associated to the NASA Astrobiology Institute, Ctra. De Ajalvir, km. 4, 28850 Torrejon de Ardoz, \\ Madrid, Spain; E-mail: jmfrias@cab.inta-csic.es \\ 2 Ilustre Colegio Oficial de Geólogos, c/ Raquel Meller, 7, 28027, Madrid, Spain; E-mail: jlgonzalez@icog.es \\ 3 Unidad Asociada UVA-CSIC, Edificio INDITI, Parque Tecnológico de Boecillo, 47152 Boecillo, Valladolid, Spain. E-mail:rull@fmc.uva.es
}

Geoscientists's professional duties go beyond scientific and technological knowledge and skills. Ethics is part of their (our) professional responsibility. Geoethics was born in 1991 at the junction of Ethics and Geology, and it has unequivocally shown a spectacular advance in the last two decades linking different disciplines, applying different methodological procedures and technologies, and facing new scientific, social and cultural challenges. However, geoethics as a discipline is still not yet very well known. Broadly, deontology is one of the main ethical decision-making approaches which are concerned with doing what is correct, in other words one of those kinds of normative theories regarding which choices are morally required, forbidden, or permitted. In this contribution we examine the origin, grounds and evolution of geoethics, emphasizing its multidisciplinary significance at different levels and institutions/organizations, providing new information regarding its recent integration in the geological and deontological context, and calling attention to the advance which represents its incorporation to the current and future developments in Planetary Geology and Astrobiology (e.g. Planetary Protection). It is unequivocally stated that geoethical issues concern all of us as Earth and Planetary Scientists.

\section{Introduction}

Considerable progress in science and technology has been achieved in the past century. Geoscientists have new skills and tasks linking different disciplines, applying different methodological procedures and technologies, and facing new scientific, social and cultural challenges, from micro- to macro-scale studies, and from land, atmosphere and oceans to planetary exploration (including their responsibility and implications in the search for life beyond Earth given the significant role of planetary geology in astrobiology). Hence, Ethics and Science (Geoscience) are inextricably bound together. Nevertheless, it is important to note that "ethics as a code" is not exactly the same as "ethics as a process" (Jickling, 1996) and this has also an influence in Geoethics. Some authors suggest that ethics as an intellectual process is "for questioning assumptions, examining arguments, weighing competing claims, and making judgements in order to come to a decision" (Andrew and Robottom, 2001). In our view, any geoethical action should reflect, among other things, freedom, scientific and professional skills, integrity and good practices, reflection, socio-cultural and human dimension and principles and motivations. Geoethics has unequivocally shown a spectacular progress in the last two decades. However, as a field it is still not very well known, and most of the Geoethics-related publications correspond to congress communications (258 from 25 countries between 1992 and 2009 at the Mining Pribram symposia and 60 at the International Geological Congresses between 1992 and 2008; Nemec, 2011), covering a great range of aspects and topics. In fact, a specific search of the terms "geoethics/geoethical" in the prestigious ISI Web of Knowledge ${ }^{\text {SM }}$ yields only one journal article (Ahluwalia, 2006) and six other items, which are abstracts from conference proceedings. The main goals of this contribution are: (1) to depict how geoethics correlates with deontology, outlining the main ethical-decision making approaches, and the state-of-the-art in the global scenario; (2) to summarize the fundamentals about geoethics, its institutionalization and current development; (3) to emphasize the significance of geoethics, providing primary information about its incorporation, for the first time, in a deontological code: the new deontological code of the Official Spanish Association of Professional Geologists, and (4) to highlight the innovation and progress which represents the incorporation of Geoethics to the current and future developments in Planetary Sciences.

\section{Generic principles, ethical approaches and global framework}

Without attempting to be exhaustive, ethics is defined as: (1) "the philosophical study of the moral value of human conduct, and of the rules or principles that ought to govern it"; (2) "a code of behaviour considered correct, especially that of a particular group, profession, or individual" and (3) "the moral fitness of a decision, course of action, etc". (Collins English Dictionary). More specifically, professional ethics refers to "those principles that are intended to define the rights and responsibilities of scientists in their relationship with each other and with other parties including employers, research subjects, clients, students, etc." (Chalk et al. 1980).

It is generally accepted that some principal ethical decisionmaking approaches are: (a) deontology: concerned with doing what 
is correct. Certain actions or rules are correct, regardless of the consequence they produce. The term deontology derives from the Greek words for duty (deon) and science (or study) of (logos). In modern moral philosophy, "deontology is one of those kinds of normative theories regarding which choices are morally required, forbidden, or permitted" (Alexander and Moore, 2008); (b) virtue ethics: taking into account motive or character; (c) consequentialism: considering foreseeable or truthful results; assessment of possible outcomes, and (d) casuistry: comparison with uncontroversial cases; deep case study to deduce general rules.

In a global framework, it can be said that the triangle involving ethics, deontology and life sciences has been extremely succesful. Since the 1970s, UNESCO has been developing and strengthening linkages among ethicists, scientists (mainly life scientists) and politicians to assist its Member States in establishing sound and consistent actions on ethical issues in science and technology (UNESCO, 2011a). UNESCO's Global Ethics Observatory (GEObs) was launched, in 2005, at the meeting of the International Bioethics Committee (IBC) in Tokyo, attempting to become a database of all currently available resources on ethics worldwide (UNESCO, 2011b). Nowadays, thanks to the GEObs, numerous resources, mainly (although not only) focused on bioethics, are already fully available and easily accessible via the internet. In the context of science and technology, other hot topics as climate change, environmental ethics, and even some emerging ethical issues are also included from different perspectives. GEObs represents the result of an extraordinary effort comprising six global network databases: (1) Who is Who in Ethics; (2) Ethics Institutions; (3) Ethics Teaching Programmes; (4) Ethics Related Legislation and Guidelines; (5) Codes of Conduct, and (6) Resources in Ethics. But, does this state-of-the-art reflect the reality and multiple multi-disciplinary links of ethics worldwide? What about the ethical issues related with geosciences and the "abiotic world" per se? What about Geoethics?

\section{Geoethics: Fundamentals and general overview}

Geoethics was born in 1991 at the junction of Ethics and geology (Nemec, 2005) despite the term being later used with various meanings which are not directly related to Geology and Geosciences (see, for instance, Rothblatt, 2003, Cascio 2005, Brillard and Brennetot, 2009, Pumain, 2009, Brennetot, 2010). Of these different meanings, the geographical view (Pumain, 2009) of geoethics is the conceptual approach which seems to be more likely related with the focus described in the present contribution. Broadly, it derives from 1996, when a group of geographers from North America and the UK envisioned exploring more thoroughly the relationship of geography and moral philosophy (Proctor, 1996), and a specific listserv named "Geo-Ethics" was made on geography, ethics and justice (Lynn, 1996). At present, there is a specific journal (GeoJournal), which includes "GeoEthics" (with this explicit geographical/spatial component), as one of the emerging new fields in the social sciences and humanities.

Although not specifically related with the term "Geoethics", the outstanding conference on "Ethics in the Geosciences" which was held in 1997 in Welches, Oregon is worth mentioning. This event was a Geological Society of America (GSA) Presidential Conference and was co-sponsored by different associations, institutes and organizations (e.g. GSA Foundation, USGS) (GSA Today, 1996; Stephenson, 1997).

As previously mentioned, Geoethics was born in 1991, and it was established as an independent scientific field in 1992, in the context of the symposium "The Mining Pøibram in science and technique". Dr. Vaclav Nemec (since 2004 Vicepresident for Europe of the Association of Geoscientists for International Development - AGID, Head of the AGID Working Group for Geoethics) is considered the father of this discipline. As Nemec stated "he was inspired by the field of business ethics, where his wife, Lidmila Nemcova, had been engaged, as represented by the prestigious French Professor Jean Moussé” (see, for instance, Moussé, 2001), to start to investigate problems of ethics applied to the Earth sciences. In a similar conceptual line, Szabó (1997) considered the GAIA hypothesis, and how the principles of geoethics should help to respect the limits of disturbances and loading capacity of ecosystems, which is essential for our survival. At the beginning of the 90's, there was an intense debate about what should be its most correct etymological meaning, and its development has followed different principles, considering theoretical, applied, methodological and educational aspects. Regular symposia on Geoethics have been organised at the International Geological Congresses since 1996, and more frequent regular meetings to this subject have been taken place at the prestigious International Section "Geoethics" at the Mining Pøíbram Symposia (Czech Republic) (see Senatskaya and Nemec, 2003, or "Geoethics News" for further information). Other geoethical-bearing meetings, workshops and specific sessions and initiatives have been organized in quite differing extensions, among others, in Japan, China, Poland, Germany, regularly in Russia (in the frame of biannual conferences "New Ideas in Earth Sciences" in Moscow since 1997), and Italy (in the context of GEOITALIA since 2009). All experts agreed that Geoethics should integrate moral principles with special regard to the Earth as a geological body, as well as social, cultural and economic aspects of all varieties.

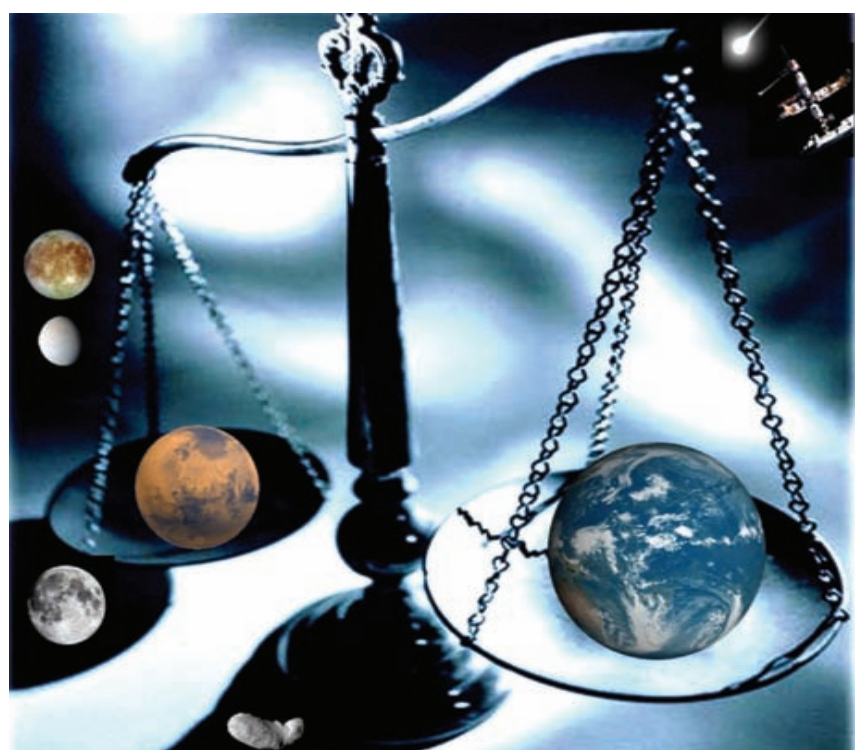

Figure 1. Geoethics logo of the AGID National Chapter in Spain. The website is hosted in TIERRA: Spanish Thematic Network of Earth and Planetary Sciences, and has the institutional backing of RedIris: National Research and Education Network for Spain, and the Spanish Association of Professional Geologists (ICOG) http:/ /tierra.rediris.es/Geoethics_Planetary_Protection/ 
The international institutionalisation of geoethics was established in 2004, by forming a working group for Geoethics with the backing of the Association of Geoscientists for International Development (AGID). Therefore in 2008 Geoethics was for the first time incorporated in the official programme of the $33^{\text {rd }}$ International Geological Congress under the auspices of AGID in Oslo (Nìmec and Nìmcová, 2008), whereas the previous symposia to this object in previous Congresses were mostly based on a "private" initiation of Vaclav Nemec, Lidmila Nemcova and once also of Professor W.S. Fyfe (former IUGS President). In 2009 a specific website mainly devoted to Geoethics was founded (Fig.1) by one of the authors of the present article (JMF), in the context of the working activities of the AGID Spanish Chapter. Such website is currently being used as the international site for Geoethics. Among other news and links, the website hosts all "Geoethics News", prepared by Dr. Vaclav Nemec since 2007 (Nemec, 2011). In 2011 a new international, peer review, open access journal "Geosciences" was introduced, which, for the first time, comprises Geoethics as one of its subject areas (MartinezFrias, 2011a). This same year, Geoethics starts in the social networks (facebook and twitter - @GeoEthics_AGID), in an interconnected way, mainly for the diffusion of news and other public outreach purposes.

\section{Deontological applications}

As it is implicit in numerous geoethics-related publications, in several codes of conduct (see GSA, EFG, The Geological Society, AIPG, AAPG, among others) and, more in particular, in the previously mentioned Geological Society of America (GSA) Presidential Conference, a general consensus exists with regards to the deontological applications of geoscientific activities: our professional duties go beyond scientific knowledge and skills. The individual geoscientists all around the world must realize that ethics is part of their (own) professional responsibility (Stephenson, 1997). It is obvious that deontological applications of Geoethics are of a great importance, mainly, but not only, in the context of the study and management of geological hazards and disasters (Ahluwalia, 2006, Fryer, 2011) (e.g. tsunamis, earthquakes, landslides, volcanoes) (Fig.2) and Earth resources (e.g. water, minerals). At present, Geoethics has been accepted by both Earth and social sciences "because the necessity of an appropriate ethical attitude to the whole geosphere and of a critical analysis of geoethical dilemmas and finding ways how to solve them" (Nemec dixit). In this sense, it is of interest to highlight that: (1) after an invited presentation on Geoethics in 2010, the prestigious Committe on Ethics of the Spanish National Research Council (CSIC) has agreed to link the AGID website on Geoethics, and (2) "Geoethics" has been expressly included, for the first time, in a geological deontological code: the new deontological code of the Official Spanish Association of Professional Geologists (Article 4: Compromises with Geoethics, ICOG, 2011). The new ICOG's code is principally based on the principles of caution, sustainability and human security. The incorporation of such geoethical values confers a new dimension to the activities of professional geologists in numerous fields of work, such as, among others, the rational use of environment and natural resources, protection of geodiversity, predictability, mitigation and management of natural hazards and disasters, and the scientific, academic and professional cooperation for development, among others. In an analogous line of action, the

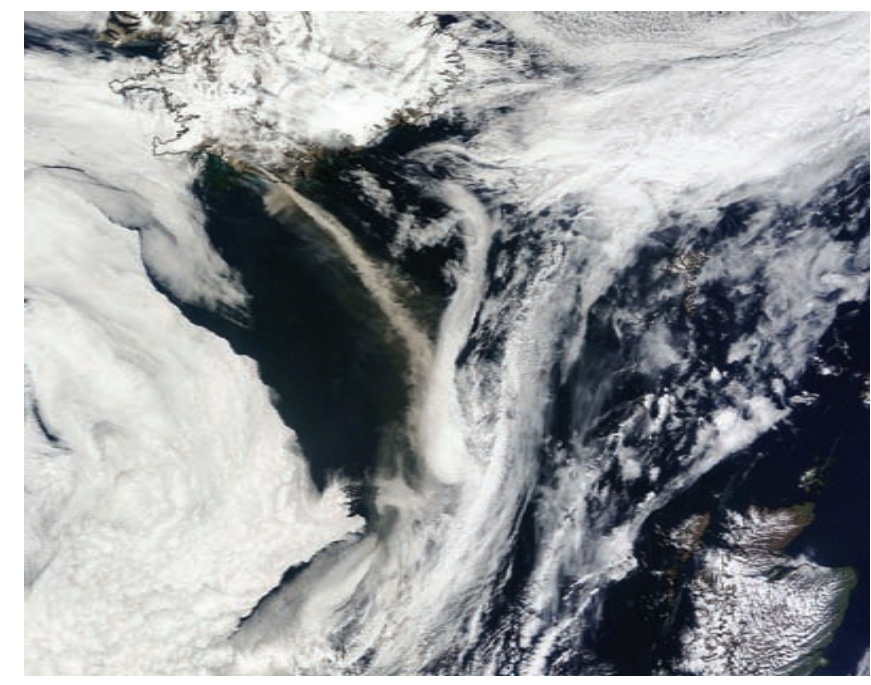

Figure 2. The Moderate Resolution Imaging Spectroradiometer (MODIS) on NASA's Terra satellite captured this image of the Eyjafjallajokull Volcano's ash plume on May 7, 2010. Credit: NASA Goddard/MODIS Rapid Response Team. Officials closed Europe's airspace for days because of the risk of ash scouring planes or being sucked into jet engines and shutting them down. Recently, it is scientifically demonstrated (Gislason et al. 2011) that it was correct to ground aircraft for seven days after the Icelandic volcano's eruption. "Aviation authorities made the right decision". This is an excellent example of geoethical collaboration between scientists and authorities which was explicitly stressed and discussed in our Geoethics Group.

Committee on Geoethics created inside the FIST (Italian Federation of Earth Sciences) plans to propose, in the context of the conference GeoItalia 2011 (Torino, 19-23 September 2011), the possible introduction of an "Oath for Geoscientists" similar to the Hippocratic Oath for doctors, that every new geologist would have to pronounce at the moment of the degree (Peppoloni, 2011; Ruggero et al. 2011). Finally, the next year, the $34^{\text {th }}$ Session of the International Geological Congress (IGC), in Brisbane, Australia will host again a special Geoethics symposium (within the Theme: Geoscience Benefiting Low Income Countries) and a (still tentative) training workshop: The Importance of Geoethics with Particular Reference to Low Income Countries (http://www.34igc.org/), both under the backing of AGID.

\section{New planetary perspectives}

It is unquestionable that Geoethics is opening its way in the institutions and organizations on which it focuses, but also in its conceptual application to the new scenarios on Earth and beyond. In this sense, it has been proposed that the incorporation of the geoethical and geodiversity issues in planetary geology and astrobiology studies would enrich their methodological and conceptual character (Martinez-Frias, 2008, Martinez-Frias et al. 2009 a,b,c). It is well known that planetary exploration and research is one of the humankind's most outstanding and exciting challenges, which requires not only scientific and technological interdisciplinary cooperation, but also the thoughtfulness of potential ethical and scientific integrity issues. At present, space agencies, through the well-established Planetary Protection requirements (Rummel et al. 2002, Rummel and 
Billings, 2004), are committed to preventing all types of biological contamination during space exploration, and preserving the planetary conditions, mainly considering biological and bioethical topics. The incorporation, through Geoethics, of new questions associated to the "abiotic world" is, besides widening the classical concept of Planetary Protection, giving an additional dimension to the geological research of the solar system (including the study of meteorites, asteroids, comets, planets and moons). This view is, in a certain way, similar to the Rolston's ideas. This author proposes that nature itself is the most valuable thing of all (Rolston, 1988, 1992, 1994). He states: "We confront a projective nature, one restlessly full of projects - stars, comets, planets, moons, and also rocks, crystals, rivers, canyons, seas. The life in which these astronomical and geological processes culminate is still more impressive, but it is of a piece with the whole projective system .... Nature is a fountain of life, and the whole fountain - not just the life that issues fiom it - is of value (1988, p. 197)". Thus, inanimate objects and the abiotic processes of nature also possess objective value under Rolston's ethic (Sheppard, 2000).

Therefore, the new planetary facet of Geoethics involves a new paradigmatic use of the term, extending the scope of the definition of Geoethics beyond the Earth (although maintaining the original Nemec's foundational spirit) (Nemec, 1992). Taking into account this additional perspective, the following formal definition of Geoethics is proposed (Martinez-Frias, 2008): Geoethics is a key discipline in the field of Earth and Planetary Sciences, which involves scientific, technological, methodological and social-cultural aspects (e.g. sustainability, development, museology), but also the necessity of considering appropriate protocols, scientific integrity issues and a code of good practice, regarding the study of the abiotic world. Studies on planetary geology (sensu lato) and astrobiology also require a geoethical approach.

\section{Final remarks}

Since its inception by UNESCO in 1998, the World Commission on the Ethics of Scientific Knowledge and Technology (COMEST) is the advisory body and forum of reflection composed which "is mandated to formulate ethical principles that could provide decisionmakers with criteria that extend beyond purely economic considerations". We accept, following Didier (2008) that "with the progress of science and technology and with questions arising on globalization, ethical issues, in particular bioethics, concerns us all'. But, as discussed in the present contribution, this quotation is not reflecting the complete panorama, as "geoethical issues also concern us all". It is important to note that Geoethics, as new discipline, is not integrated in the UNESCO's Global Ethics Observatory database (GEObs). There are no geoethical experts in the GEObs' Who's is Who, and it is not possible to find any geoethics related institution (e.g. AGID), or any of the more than 300 scientific contributions (e.g. Geoethics sessions at the Mining Pribram symposia, International Geological Congresses). All these resources should be considered and updated by COMEST and GEObs, in the context of Ethics of Science and Technology. In our view, this unjust situation should be revised and corrected.

One of the first aspects related with the first stages of geoethics were presented in the Kyoto International Geological Congress in the section "New ideas and techniques in geological education" (Nemec, 1992). Paradoxically, this educational facet is, in our view, one of the most significant aspects for its worldwide development, which connects with the current state-of-the-art of geoethics. Very recently, through the IUGS Commission on Geoscience Education, Training and Technology Transfer, the need of this connection was emphasized (Martinez-Frias, 2011b) in the context of the extraordinary celebration of the IUGS $50^{\text {th }}$ Anniversary(Riccardi, 2011). Geoscience education and geoethics are two terms which are intrinsically linked. $\mathrm{We}$, geoscientists, have to be aware that the main likely reason of this absence of geoethics in the databases is probably our own lack of both knowledge and appropriate care, from the level of fundamental geology to its most leading research. The true development of geoethics is, above all, a responsibility of all of us as Earth and Planetary Scientists.

\section{Acknowledgements}

The authors wish to thank Dr. Vaclav Nemec for his continuous advice, support and very useful information about Geoethics. We acknowledge two anonymous referees for their important suggestions and insights, and Prof. M. Jayananda for the editorial management of our article. Thanks also to the Association of Geoscientists for International Development (AGID), the Spanish Association of Professional Geologists (ICOG), and the National Research and Education Network for Spain (RedIRIS). This work has been supported by the MICINN project AYA2011-30291-C02-02.

\section{References}

Ahluwalia, A.D., 2006, Geoethical audit of tsunami of 26 December 2004: Challenge before leaders, media and scientists. Current Science, v. 90 , no. 6, pp. 762-764

Alexander, L. and Moore, M., 2008, "Deontological Ethics", The Stanford Encyclopaedia of Philosophy (Fall 2008 Edition), E. N. Zalta (ed.), http://plato.stanford.edu/archives/fall2008/entries/ ethics-deontological/

Andrew, J. and Robottom, I., 2001, Science and Ethics: Some Issues for Education. In Norris, S (Ed.) Science and Ethics. Issues and Trends. John Wiley \& Sons, Inc., pp. 769-780.

Billard, G. and Brennetot, A., 2009, Le périurbain a-t-il mauvaise presse ? Journal of Urban Research, 5. Online since 25 avril 2010, http://articulo.revues.org/1372

Brennetot A., 2010, Pour une géoéthique. Éléments pour une analyse des conceptions de la justice spatiale, L'Espace géographique, v. 39 , no. 1 , pp. $75-88$.

Cascio, J., 2005, Terraforming Earth, Part III: Geoethical Principles. http://www.worldchanging.com/archives/003189.html

Chalk, R., Frankel, M.S. and Chafer, S.B., 1980, AAAS Professional Ethics Project. American Association for the Advancement of Science, 1515 Massachusetts Ave. NW, Washington, D.C. 20005. AAAS Publication 80-R-4.

Collins Publishers Staff (2006) Collins Concise Dictionary and Thesaurus, HarperCollins, 4th Revised edition, pp. 1216.

Didier, E., 2008, NGO-UNESCO Liaison Committee CPM Science and ethics. Bioethics Commission IFUW-UNESCO team. http:// www.ifuw.org/docs/Bioethics_1108_English.pdf

Fryer, P. (2011) GG 406 - Natural Disasters: Geoethics and the Layman - 86661 - GG 406 - 001 Course. University of Hawaii at Manoa 
Campus http://www.sis.hawaii.edu/uhdad/avail.class?i= MAN\& $=201130 \& c=86661$

Gislason, S.R., Hassenkam, T., Nedel, S., Bovet, N., Eiriksdottir, E. S., Alfredsson, H. A., Hem, C. P., Balogh, Z. I. , Dideriksen, K. Oskarsson, N., Sigfusson, B., Larsen, G. and Stipp, S. L., 2011, Characterization of Eyjafjallajökull volcanic ash particles and a protocol for rapid risk assessment. PNAS, v. 108, no. 18, pp. 73077312

GSA Today, 1996, Ethics in the Geosciences. Presidential Conference Scheduled, November 1996, pp. 6-7. Online version: http:// tierra.rediris.es/Geoethics_Planetary_Protection/ GSA_Ethics_in_the_Geosciences.pdf

ICOG: Ilustre Colegio Oficial de Geólogos. Código Deontológico. http://www.icog.es/files/CODIGO\%20DEONTOLOGICO\% 202011.pdf

Jickling, B., 1996, Wolves, ethics and education: Looking at ethics and education through The Yukon Wolf Conservation and Management Plan. In B. Jickling (Ed.), A Colloquium on Environment, Ethics, and Education. Proceedings of colloquium, Yukon College, Whitehorse, Yukon, 14 - 16. July 1995. Yukon, Canada: Arts and Science Division, Yukon College, pp. 158-163.

Lynn, W.S., 1996 Geo-Ethics listserv. http://segate.sunet.se/cgi-bin/ wa?A2=ind $9602 \& \mathrm{~L}=$ geograph $\& \mathrm{P}=2163$

Martinez-Frias, J., 2008, Geoethics: proposal of a geosciencesoriented formal definition and future planetary perspectives. TIERRA: Spanish Thematic Network of Earth and Planetary Sciences. http://tierra.rediris.es/documentos/ Geoethics_Tierra_Network_2008.pdf

Martinez-Frias, J., Rodriguez-Losada, J.A., Lunar, R., Rull, F., Madero, J., Garcia Talavera, F., Perez Verde, A. and HernandezFernandez, S., 2009a, Meteorites as geological heritage in the new Spanish legislation: current state, scientific and ethical praxis, and international implications regarding geodiversity in the Earth and Solar System. Bolides and Meteorite Falls, Prague, May 1015, pp. 14-15.

Martinez-Frias, J., Nemec, V., Nemcova, L., De la Torre, R. and Horneck, G., 2009b, The significance of Geoethics in Planetary Protection and Space Research. The International Section Geoethics Mining Pribram Symposium 2009, October 12-16, 2009, Pribram, Czech Republic.

Martinez-Frias, J., Nemec, V., Nemcova, L., De la Torre, R. and Horneck, G., 2009c, Geoethics and Geodiversity in Space Exploration: Implications in Planetary Geology and Astrobiology. 9th European Workshop on Astrobiology, EANA 09, 12-14 October 2009, Brussels, Belgiam.

Martinez-Frias, J., 2011a, Geosciences: An Open Access Journal on Earth and Planetary Sciences and Their Interdisciplinary Approaches. Geosciences, v. 1, no. 1, pp. 1-2.

Martinez-Frias, J., 2011b, IUGS/COGE: The significance of partnership, capacity building and a multidisciplinary approach in geosciences education. IUGS 50th Anniversary Event. Paris (France), http://www.iugscoge.com/pdf_files/IUGS_COGE_ 50th_Paris_JMFrias.pdf

Mousse, J., 2001, Ethique des Affaires: Liberté, Responsabilité. Le décideur face à la question éthique. http://lipsor.cnam.fr/servlet/ com.univ.collaboratif.utils.LectureFichiergw?ID_FICHIER=1295877018152

Nemec, V., 1992, Ethical Geology in the Education Process. 29th International Geological Congress, Kyoto, Japan, 24 August-3
September 1992. section II-24-1 «New ideas and techniques in geological education», v.. 3, no. 3. Abstract/Paper 06.

Nemec, V., 2005, Developing Geoethics as a new discipline http:// www.bgs.ac.uk/agid/Downloads/VN05Geoethics.pdf

Nemec, V., 2007, To the roots of Geoethics (historical reminiscence). Hornická Pøíbram ve vìdì a technice. http://slon.diamo.cz/hpvt/ 2007/SG/GD1.pdf

Nemec, V. and Nemcova, L., 2008, Geoethics session (IEE-07). 33rd International Geological Congress, Oslo, August 6-14th. http:// www.cprm.gov.br/33IGC/Sess_233.html

Nemec,V.(2011), Geoethics News; http://tierra.rediris.es/Geoethics_ Planetary_Protection/Newsletter/GeoethicsNews 11March.pdf

Peppoloni, S., 2011, Geoethics session at Geoitalia conference 2011. 19-23 September 2011 - Turin, Italy http://tierra.rediris.es/ Geoethics_Planetary_Protection/GEOETHICS_GEOITALIA.pdf

Proctor, J., 1996, Geography/Ethics Project Web Forum http:// www.cep.unt.edu/news/geoethics.html

Pumain, D., 2009, Geoadvertainment et Geoethics. Cybergeo: European Journal of Geography, Editorials: http:// cybergeo.revues.org/21883.

Riccardi, A., 2011, The 50th Anniversary of the IUGS. Episodes, v. 34 , no. 1 , pp. $57-58$.

Rolston III, H., 1988, Environmental Ethics. Duties to and Values in the Natural World. Philadelphia, Temple University Press, pp: xiii +391 .

Rolston III, H., 1992, Disvalues in Nature. The Monist, v. 75, no. 2, pp. 250-278.

Rolston III, H., 1994, Value in Nature and the Nature of Value. Philosophy (supp.), 13-30, http://lamar.colostate.edu/ rolston/ value-n.pdf

Rothblatt, M. (2003) Your Life or Mine: How Geoethics Can Resolve the Conflict between Public and Private Interests in Xenotransplantation, Dartmouth Publishing Co Ltd., pp. 196

Ruggero, M., Guido, G., Peppoloni, S., Piacente, S. And WASOWSKI, I. (2011) A Hippocratic Oath for Geologists? Sessione U1. Geoetica e cultura geologica, il contributo delle Scienze della Terra ad un rinnovamento culturale della società. GeoItalia 2011. VIII Forum Italiano di Scienze della Terra, Torino, 19-23 settembre 2011.

Rummel, J. D., Stabekis, P. D., Devincenzi, D. L., Barengoltz , J. B., 2002 "COSPAR's planetary protection policy: A consolidated draft". Advances in Space Research, v. 30, no. 6, pp. 1567-1571.

Rummel J. D., Billings L., 2004, Issues in planetary protection: policy, protocol and implementation. Space Policy, v. 20, no. 1, pp. 4954.

Senatskaya, G.S. \& Nemec, V., 2003, http://slon.diamo.cz/hpvt/2003/ sekce_g/ga/GA6.htm In: Mazur I. I. and Chumakov A. N. (2006) Globalistika: Mezhdunarodnyi Mezhdistsiplinarnyi entsiklopedicheskii Slovar, ISBN 5896740204 / 9785896740209 / 589674-020-4 ITS Elima, 1159 pp (in Russian).

Sheppard, A.L., 2000, Two rationalist-deontological approaches in environmental ethics: a critical comparison of Rolston and Taylor. Thesis Presented to The Faculty of Graduate Studies of The University of Guelph. National Library of Canada. 98 pp.

Stephenson, D., 1997, http://tierra.rediris.es/Geoethics_Planetary_ Protection/GSA_Ethics_in_the_Geosciences.pdf

Szabó, S., 1997, Geoetika a jej princípy. Acta Montanistica Slovaca Roèník, v. 2, no. 4, pp. 347-350

Zagorchev, I., 2003, 50 Years University of Mining and Geology “St. 
Ivan Rilski” Annual, vol. 46, Part IV, Humanitarian and Åconomic Sciences, Sofia, 2003, pp.5-7

UNESCO, 2011a, About the Ethics of Science and Technology Programme http://www.unesco.org/new/en/social-and-humansciences/themes/about-ethics/

UNESCO, 2011b, Global Ethics Observatory http://www.unesco.org/ new/en/social-and-human-sciences/themes/global-ethics-

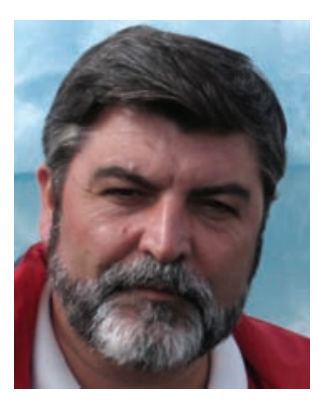

Jesus Martinez-Frias, Senior Scientist at the Spanish National Research Council (CSIC) and Professor "Ad Honorem" at the Polytechnic University of Madrid. He has participated in numerous scientific projects (e.g. IGCP, NASA, ESA, NATO) combining his expertise on Planetary Geology and Astrobiology with aspects on Geoscience Education, Science and Technology for Development and Geoethics. He is Chair of the IUGS COGE, and founder and coordinator of the AGID National Group in Spain, mainly devoted to Geoethics.

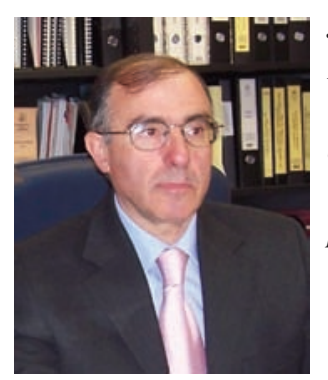

José Luis González García received a Degree in Geology, specialty of Structural Geology, from the Complutense University of Madrid. He has served as an official of the Ministry of Development in Spain. At present, he is a natural hazards analyst in the Prime Minister'Office, an ethics advisor in the Spanish Association of Professional Geologists - ICOG, and a member of the AGID National Group in Spain mainly devoted to Geoethics. Recently, he has been responsible for updating the deontological code in order to include, for first time, the geoethical principles. observatory/access-geobs/

Vincent, J., 1994, Some Canadian perceptions of environmental ethics. In J. Peepre, \& B. Jickling (Eds.), Northern Protected Areas and Wilderness. Proceedings of a Forum on Northern Protected Areas and Wilderness, Whitehorse, Yukon, November 1993. Yukon, Canada: Canadian Parks and Wildlife Society and Yukon College, vol. XIII, $379 \mathrm{p}$

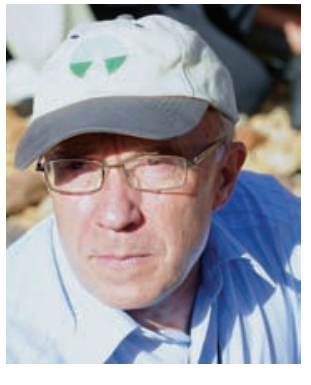

Fernando Rull. Professor at the University of Valladolid and Head of the Unidad Asociada UVA-CSIC at the Centro de Astrobiologia. He has worked for long time in Raman and IR spectroscopy with application to solids, aqueous solutions and minerals, and has intensively been involved on developing portable Raman and LIBS instrumentation for in-situ applications, both in contact and remote modes. From 2005, Prof. Rull is leading the Raman instrument on board the Exomars Mission to Mars (ESA-NASA), which will be launch on 2018. He is a member of the AGID National Group in Spain mainly devoted to Geoethics. 